\title{
MANAGING CROATIAN ENERGY LEGISLATION WITH EUROPEAN UNION ENERGY PACKAGE
}

Since Croatia started acquiring the status of a candidate for European Union (EU) membership it has been adjusting its legislation with EU requirements. Moreover, Croatian electricity sector is facing a numerous challenges and significant changes in legislation are needed in order to successfully complete the process of market liberalization. The biggest challenge in Croatian electricity sector is to achieve a $20 \%$ share of renewable energy sources (RES) in gross final energy consumption by the year 2020. Croatia currently has about $15.1 \%$ of RES in gross final energy consumption and one of the ways to achieve its goal is to increase production capacity from renewable energy sources in accordance with energy consumption. Furthermore, the opportunities for establishing economic growth through innovation and a sustainable competitive energy policy have been very well recognized in Croatia. Therefore, the overall investments in energy production from renewable sources will have significant impact on growth and employment in rural parts of country which is in line with EU RES strategy.

Key words: managing,energy strategy, renewable energy resources

\section{Introduction}

Croatia, as a member of the European Union (EU), is committed to align its energysectorwithEUobjectives, and toadoptitsgoalswithEUDirective2009/28/EC on the promotion of the use of energy from renewable sources. The Directive requires EU member states to produce a pre-agreed proportion of energy consumption from renewable energy sources (RES)such that the EU as a whole shall obtain at least $20 \%$ of total energy consumption from RES by the year 2020 . Moreover, it reinforces the 20-20-20 agenda of the EU, e.g. 20\% reduction in greenhouse gas (GHG) emissions, 20\% share of renewable energy in gross final

Barbara Dorić, Msc, Croatian Hydrocarbon Agency, Zagreb, Croatia, e-mail: barbara. doric@cei.hr

** Dinko Primorac, PhD, Assistant professor, Faculty of Economics, Croatia, e-mail: primoracdinko@gmail.com

*** Ana Jovancai, PhD, Assistant professor, Megatrend University, Serbia, e-mail: ajovancai@ megatrend.edu.rs 
consumption, and $20 \%$ reduction in energy consumption and $10 \%$ share of renewable energy in transport.

Considering EU objectives and large investment potential in developing energy markets RES isin the special focus of almost everygovernment. Therefore, most of the EU governments are trying to implement different actions in order to reach EU goals. However, if we analyzeCroatian share of RES, in gross final consumption in the year 2012,we can see it is around 15.1\% (Figure 1). For that reason, Croatian plan is that remaining $4.9 \%$ of the $20 \%$ target shareshall be produced from newly constructed renewable energy plants that Croatian government is supporting.

Figure 1: Share of RES in gross final energy consumption in Croatia (http://epp.eurostat.ec.europa.eu)

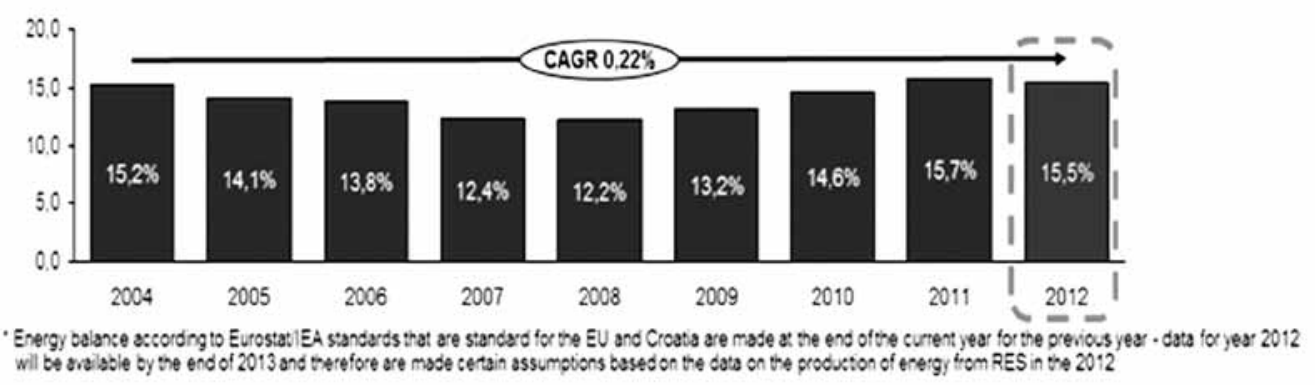

\section{Croatian energy strategy and implementation challenges}

Croatia nowadays imports nearly $30 \%$ of electricity and $75 \%$ of primary energy, and it is highly dependent on energy imports which, in the case of growth of energy prices on the international market, have far-reaching consequences for the competitiveness of the Croatian economy. Therefore,Croatian Energy Strategy (CES) was adopted by the Croatian Parliament in $2009^{1}$ setting the goal of building at least $2400 \mathrm{MW}$ of new thermal power plants, $300 \mathrm{MW}$ of large hydro, and $1655 \mathrm{MW}$ from renewable sources by the year 2020.Furthermore, after adoption of CES in the year 2009, Croatian government adopted one more strategic plan and set the goals in renewable energy sources plan (RES) of electricity production (Table 1). CES wants to retain at least a 35\% share of RES, which includes large hydro power plants (excluding pumped storages) by the year 2020, with the ultimate target of reaching at least a $20 \%$ share of RES in gross final consumption. We see that hydro power plants accounts almost $30 \%$ of the RES electricity balance, but we need to consider that even hydro energy costs are low, the down side of hydro energy production is consequently large dependence on hydrological conditions.

Croatian Energy Strategy (CES), source: http://narodne-novine.nn.hr 
Table 1: Plan of electricity production from renewable energy sources by the year 2020. (http://www.mingo.hr)

\begin{tabular}{|l|c|}
\hline \multicolumn{1}{|c|}{ Renewable energy sources } & Megawatts \\
\hline Wind power plants & 1200 \\
\hline Solar power plants & 45 \\
\hline Small hydro power plants & 100 \\
\hline Biomass & 140 \\
\hline Biogas & 110 \\
\hline Municipal waste & 40 \\
\hline Geothermal power plants & 20 \\
\hline
\end{tabular}

From Table1 it is clearly seen that Croatian government based its development strategy ofRES mostly on wind plants (72.5\%). However, this energy strategy is based on the assumption of gross final energy consumption with annual growth of $2.7 \%$, which is not in accordance with the current decline in consumption of $1.3 \%$ per annum, whereas gross final energy consumption in the year 2011 reduced by $2.5 \%$ compared to the year 2010 (Figure 2). Moreover, in the period from 2006 to 2011 a final energy consumption reduction trend was observed at an average annual rate of $1.3 \%$. Therefore, as it is not likely that the predicted consumption growth will occur, and the given estimations should be revised.

Figure 2: Trends in Croatian final energy consumption (http://www.eihp.hr/hrvatski/projekti/EUH_od_45/EUH11web.pdf)

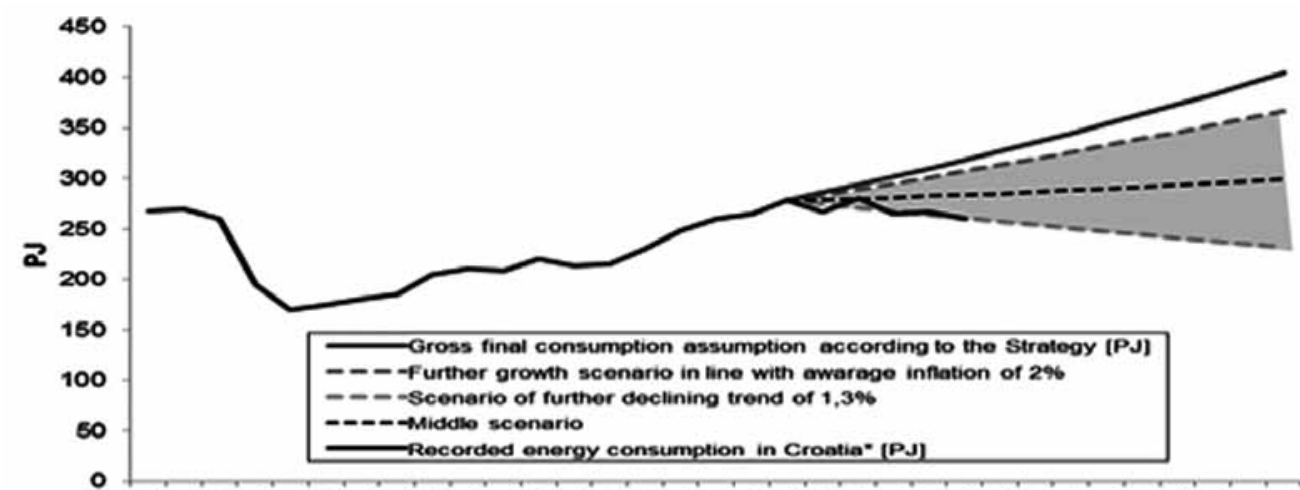

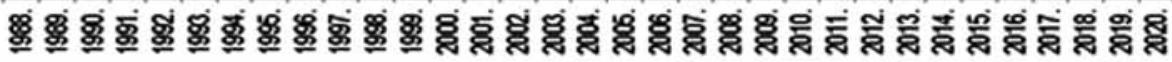

Revisingpredictions on consumption growth has a direct impact on the goals of RES which also impacts installed capacity targets by the year 2020, and construction of an incentive system to support implementation of new RES. 


\section{Analysis of Croatian current situation}

Now days, three year after Croatian Energy Strategy was adopted, we can see that it has very low implementation rate regarding renewable energy sources projects. Progress of newly constructed RES projects towards targets set in the Energy Strategy is only $13.8 \%$ (Figure 3). Poor implementation of RES projects is a consequence of legal, technical and financial barriers, as well as lack of cooperation between institutions which all contributed to making the administrative procedure for RES to become lengthy,with inherent uncertainties and risk for prospective investors. Also, due to specifics of the Croatian electricity gridit is questionable whether the strategy goals are realistic.

Figure 3: RES projects in March 2013 (MW) that are connected to the grid by types in relation to the objectives defined by the Croatian Energy Strategy (http://oie-aplikacije.mingo.hr/pregledi/)

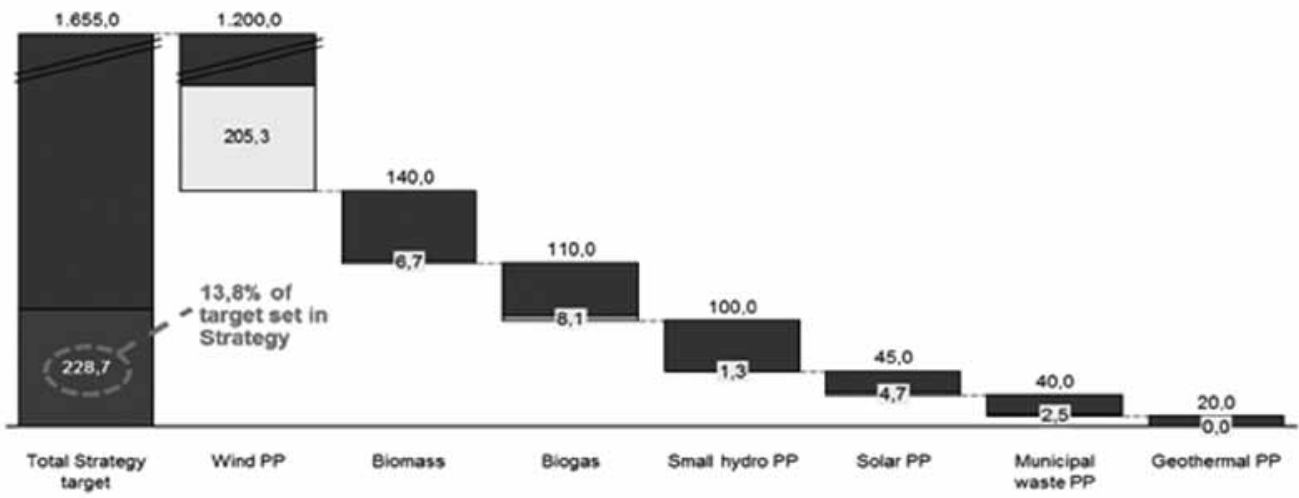

3.1. Wind power plants

Croatia has a high potential for the realization of wind power. However, due to the lack of secondary regulation power in the system the capacity is limited to $400 \mathrm{MW}$, which will be achieved by the year 2015. In the Registry of renewable energy projects and cogeneration (OIEKPP Registry) ${ }^{2}$ there are 4,267 MW of registered projects in various stages of implementation. The current technical potential of the transmission system enables connection of $400 \mathrm{MW}$ without loss of system stability. For this purpose a quota system was established for wind energy projects.

2 OIEKPP Registry, source: http://solarserdar.wordpress.com 
Figure 4: Overview of wind power projects in progress March 2013 (MW)

(http://oie-aplikacije.mingo.hr/preglediand http://www.hep.hr)

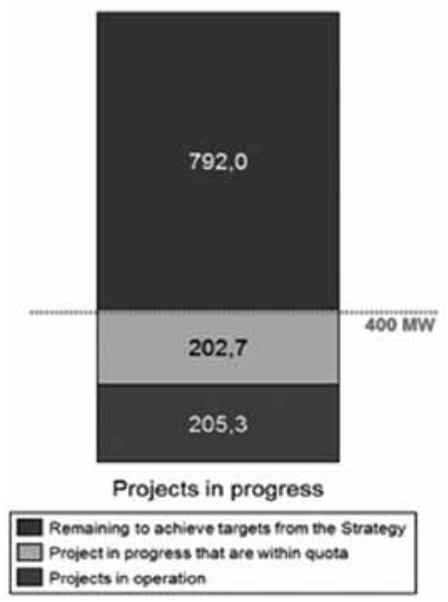

The quota of $400 \mathrm{MW}$ consists of 205,3 MW of wind power plants already in operation and 202,7 MW for which implementation (commissioning) is planned in 2014, and they are all within the quota (Figure 4). Solutions for expansion of secondary regulation capacity in the network are currently being developed to ensure the successful implementation of new wind power plants, but timeframe for expansion is not yet known.

\subsection{Solar power plants}

There are 4,7 MW of solar power plants (photovoltaic) operational in Croatia and in the near future connection of additional 31,7 MW is expected. In the OIEKPP Registrythere are 340 registered projects with a total installed capacity of $86,7 \mathrm{MW}$ in various stages of implementation. There are no technical limitations to the growth of the number of connections to the network. Currently the only limitation on solar power plants is the annual quota that is defined by the Croatian energy market operator (HROTE) ${ }^{3}$, formed due to limitations in the resources available for the payment of incentives. From the year 2007 to 2012 quota for integrated solar power plants was $1 \mathrm{MW}$ while $7 \mathrm{MW}$ was contracted. Forthe year 2012quotas for integrated solar systems (installed on buildings) were $10 \mathrm{MW}$ and $5 \mathrm{MW}$ for non-integrated. For the year 2013 quota for integrated solar systems is set at $15 \mathrm{MW}$ and $10 \mathrm{MW}$ for non-integrated. All quotas for integrated systemshave been filled. However, since there are only 4,7 MW of projects currently in operation, it is necessary to change the way of calculating fulfilment of quotas (currently it is calculatedas projects that have signed a contract with HROTE, and it should be calculated as project that already started operation).

HROTE, source: http://www.hrote.hr 
Furthermore, given the small annual energy production and the benefits of distributed generation, there are no obstacles to a large increase of targets.

Figure 5: Overview of solar power plants projects in progress March 2013 (MW) (http://oie-aplikacije.mingo.hr/pregledi andhttp://www.hrote.hr)

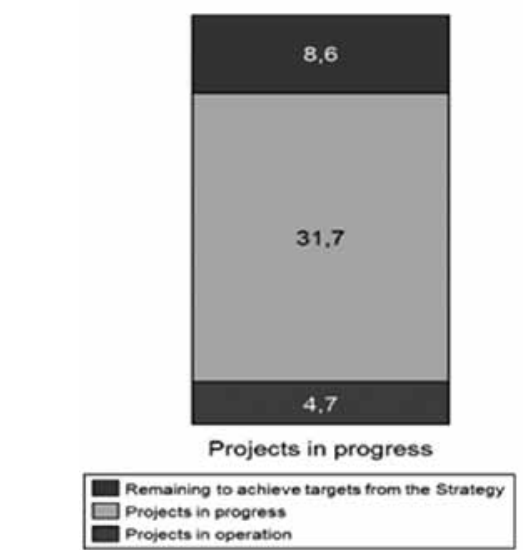

\subsection{Small hydro power plants (SHPP)}

There are currently1,3 MW of SHPP operational in Croatia, while additional $0,3 \mathrm{MW}$ is under construction. However, a number of key permits for project initiation "the previous energy approvals" have expired. Currently there are only 3 'previous energy approvals' which are still valid, along with 5 'energy approvals' (a permit for plant construction in advanced implementation stages, subsequent to location permit), for a total capacity of 5,4 MW. OIEKPP Registry has 63 registered projects with a total installed capacity of $128,8 \mathrm{MW}$ in various stages of implementation, but expected realization is low although there are no technical limitations for connection to the grid.

Figure 6: Overview of small hydro power plants projects in progress March 2013 (MW) (http://oie-aplikacije.mingo.hr/pregledi and http://www.hrote.hr)

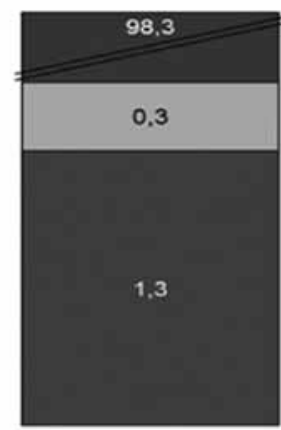

Projects in progress

Remaining to achiove tarpets from the Strategy 
Part of the areas viable for construction of SHPP is covered by the Natura 2000 network $^{4}$ which complicates construction. In Croatia there is very small interest for small hydropower plants and the implementation of projects is poor due to the risk and long administrative procedures. Furthermore, due to a small number of remaining locations with unrealized hydro potential, it is unlikely that there will be more than $100 \mathrm{MW}$ of SHPP implemented in total.

\subsection{Biomass power plants}

Currently there are 6,7 MW of biomass plants operational in Croatia, while $46 \mathrm{MW}$ are at an advanced stage of implementation, e.g. have signed contracts for procurement of raw material from Croatian Forestry. A consolidated list of projects from OIEKPP Registry and Ministry of Economy reports contains 102 projects with a total installed capacity of $256,82 \mathrm{MW}$ and its needed to say that there are no technical limitations for connection to the grid. According to the issued energy approvals, a realization of $77,5 \%$ of the target set in the Energy Strategy can be expected by 2015. Furthermore, given the maturity of the technology a large investor interest is expected. There are also synergies possible with the wood industry for simultaneous generation of electricity and heat from RES. The target goal for biomass plants should be increased.

Figure 7: Overview of biomass hydro power plants projects in progress March 2013 (MW) (http://oie-aplikacije.mingo.hr/pregledi and http://www.hrote.hr)

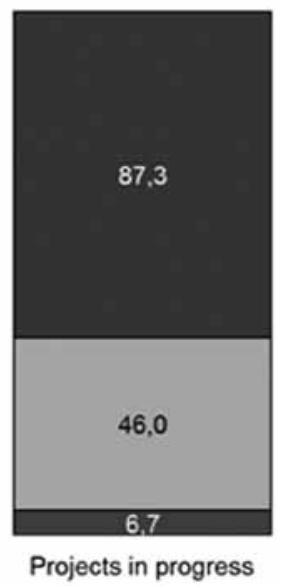

Remaining to achieve targets from the Strategy

Projects in operation

Natura 2000 network, source: http://ec.europa.eu/environment/nature/natura2000 


\subsection{Biogas power plant}

There are currently 8 plantsoperational in Croatia with a total capacity of 8 , $1 \mathrm{MW}$ while 4 plants with total capacity of 7,5 MW are in the stage of construction. In OIEKPP Registry there are 51 registered projects with a total installed capacity of 77,91MW in various stages of implementation. There are no technical limitations for connection to the grid for this kind of plants but there's potential depends on the ability of simultaneous delivery of electricity and heat to nearby consumers. Due to high investment costs of biogas plants in the current market, biogas projects are less attractive to investors compared to other sources. So far, investors' interest is not satisfactory to realize target of $110 \mathrm{MW}$ set in the CES.

Figure 8: Overview of biogas power plants projects in progress March 2013 (MW) (http://oie-aplikacije.mingo.hr/pregledi and http://www.hrote.hr)

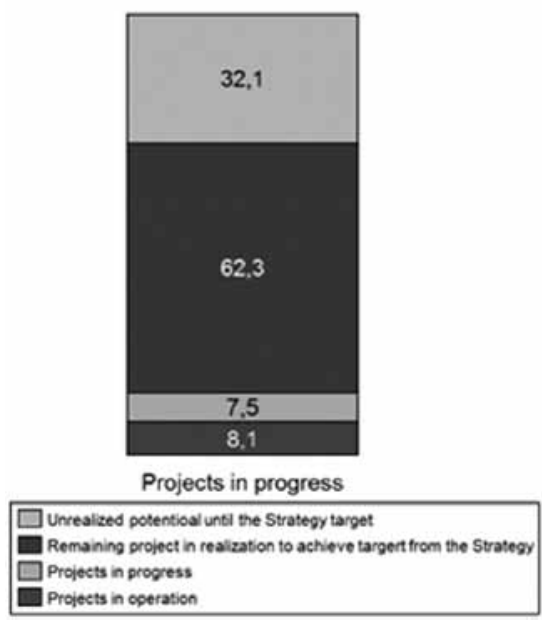

\section{Conclusion}

After the study of Croatian Energy Strategy and after analyzing renewable resources power plant implementation wecan conclude that certain changes are needed to be implemented in this strategy immediately. In order to achieve the target share of RES in gross final consumption, according to EU obligations, goals of the Croatian Energy Strategy should be revised.

In the time when the Croatian Energy Strategy was made the government has not thought that world economy crisis will effects economy in so big scale. Moreover, projections for the year 2020 were based on stable growth of the economy while the reality was a huge recession in the world. In-depth analysis of barriers in the administrative procedure for the implementation of RES projects should be made. Also, the dynamics of RES projects implementation is not sat- 
isfactory. The government should be aware that presumption of grid development to accept the $1200 \mathrm{MW}$ wind power has not been jet achieved. Also, the plants for the production of renewable heat, which are also included the target of $20 \%$ RES in EU, do not represent a significant burden on the grid and are not adequately addressed in energy policy. Moreover, the energy production from solar power plants is much cheaper now due to technological progress and is nowadays suitable for mass implementation.

We often witness that investors display huge interest for renewable power plants, while the strategy makersdo not prepare the county's strategy planwell; do not consider maturity of the technologies and the time required for project implementation in the design of the system.The construction of new power plants is essential for Croatia due to high dependence on imports and hydrological conditions, which can vary significantly in the short-term and mid-term. In the long-term RES is the optimal choice for new capacities since it do not depend on fuel costs or disturbances in foreign markets. The strategy has to set development principles according to which Croatia will become an exporter of energy, and its energy sector will become more profitable. At the time finishing this article a new indication are seen that the Croatian government will make new, critical step which will be in focus of achieving Croatian energy independence.

\section{Literature}

- $\quad$ EU Directive 2009/28/EC. Retrieved 03.07.2013 from http://eur-lex.europa.eu.

- Croatian Energy Strategy.Retrieved 03.07.2013 from http://www.mingo.hr.

- Energy Institute HrvojePožar.Retrivered03.07.2013 from http://www.eihp.hr.

- Croatian centre of renewable energy sources. Retrivered 03.07.2013 from Ministry of Economy. Retrieved 03.07.2013 from http://oie-aplikacije.mingo. hr/pregledi.

- Croatian transmission system operator. Retrieved 03.07.2013 from http:// www.hep.hr.

- Croatian energy market operator. Retrieved 03.07.2013 from http://www. hrote.hr. 
Barbara Dorić, doktorand

Hrvatska agencija za ugljikovodike, Zagreb, Hrvatska

Doc. dr Dinko Primorac,

Ekonomski fakultet, Hrvatska

Doc. dr Ana Jovancai,

Megatrend univerziteta, Srbija

\title{
USKLAĐIVANJE HRVATSKOG ENERGETSKOG ZAKONA SA ENERGETSKIM PAKETOM EVROPSKE UNIJE
}

\begin{abstract}
S a ž e t a k
Od kada je Hrvatska stekla status kandidata za članstvo Evropske unije (EU) započela je sa usklađivanjem zakonodavstva u skladu sa propisima EU. Osim toga, hrvatski sektor za električnu energiju suočava se sa brojnim izazovima tako da su potrebne značajne promene $u$ okviru zakonodavstva kako bi proces liberalizacije tržišta bio uspešan. Najveći izazov u hrvatskom sektoru električne energije je ostvariti $20 \%$ udela obnovljivih izvora energije (RES) u bruto energetskoj potrošnji do 2020. Hrvatska trenutno ima oko 15.1\% RES u konačnoj bruto potrošnji energijei jedan od načina da ostvari svoj cilj je da poveća kapacitet proizvodnje obnovljivih izvora energije u skladu sa malom potrošnjom energije. Pored toga, mogućnosti za uspostavljanje ekonomskog rasta putem inovacija i održive konkurentske prednosti u razvoju energetske politike, veoma su priznate u Hrvatskoj. Dakle, ukupna ulaganja u proizvodnju energije iz obnovljivih izvora imaće značajan uticaj na ekonomski rast i zaposlenost u ruralnim delovima zemlje a koja su u skladu sa strategijom EU RES.
\end{abstract}

Ključne reči: upravljanje, energetska strategija, obnovljivi izvori energije 